JOURNAL OF
NATURAL RESOURCES
AND DEVELOPMENT

Research article

\title{
Assessment of Spatial Soil Erosion Susceptibility Based on the CORINE Model in the Gumara-Maksegnit
}

\section{Watershed, Ethiopia}

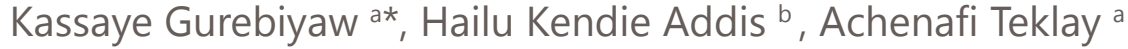 \\ a Department of Natural Resources Management, College of Agriculture and Rural Transformation, University of Gondar, Gondar, Ethiopia \\ ${ }^{b}$ Gondar Agricultural Research Centre (GARC), Amhara Agricultural Research Institute (ARARI), Gondar, Ethiopia
}

* Corresponding author: kassayegurebiyaw@gmail.com kassaye.gurebiyaw@uog.edu.et

\section{Article history}

Received 29/01/2018

Accepted 12/05/2018

Published 25/05/2018

\section{Keywords}

Actual erosion risk

Climate

GIS

Potential erosion risk

Soil erosion

\section{Abstract}

Soil erosion is one of the major environmental threats in the northwestern Amhara Region of Ethiopia. The objective of this study is to assess the spatial heterogeneity of soil erosion risk within the GumaraMaksegnit watershed $\left(57.3 \mathrm{~km}^{2}\right)$ using the Coordination of Information on the Environment (CORINE) soil erosion assessment method to determine the most endangered areas. The model is simple and robust and consists of six steps overlaying combinations of soil texture, depth, stoniness, climatic and land-use/land-cover information with GIS support. The CORINE model was used to produce potential and actual soil erosion maps. The potential soil erosion map consists of the erosion risk of the land without considering current vegetation, but can be expanded to consider current land cover. The potential soil erosion risk map showed that a small part of the watershed (6.63\%) had low risk, 17.92 $\%$ had moderate risk and a large part of the study area (75.45 \%) had high potential erosion risk. Meanwhile, the actual soil erosion risk map showed that a small part of the watershed (11.92 \%) had low risk, $20.85 \%$ of the area had moderate risk, and a large part of the study area (67.23\%) had high actual soil erosion risk. Low soil erosion risk areas were located in the southern part of the watershed, high erosion risk areas were found in the northern, northwestern and eastern part of the watershed, while moderately risky areas were randomly distributed throughout the watershed. Overall, the CORINE model can play a role in soil and water conservation by identifying highly endangered areas.

(c) 2018 This is an open access article under the CC BY-NC-ND license (http://creativecommons.org/licenses/bync-nd/4.0/). 


\section{Introduction}

Soil erosion is a serious problem throughout the world due to its adverse economic and environmental impacts [1]. In developing countries, where agriculture is the main source of income and a significant contributor to the economy, soil erosion poses a common threat. In Ethiopia soil erosion by water contributes significantly to food insecurity among rural households and poses a real threat to the sustainability of existing subsistence agriculture by deteriorating the amount of soil and its quality [2]-[5]. It not only diminishes the quality of soil resources but also makes earning a living from the land increasingly difficult. Reduced productivity of the soil affects outputs such as crop yields derived from the renewable nutrient system of the biosphere [6]. It also negatively impacts the natural water storage capacity of the catchment areas of man-made reservoirs and dams, the quality of surface water, aesthetic landscape beauty and ecological balance in general [1], [6], [7].

Although losses of topsoil by erosion are widely considered to reduce productivity, this has not been well quantified over a wide range of soils [8]-[15]. Despite several significant trends revealed by plot-scale erosion studies, there are obvious reasons why such studies may not represent the general erosion processes on a basin or watershed level. This may be due to the basin or watershed covers various agroecology and geological conditions as well as a range of different land management and topographic characteristics. The application of computer based watershed models can help to save time and money because of their ability to perform long-term simulations of the effects of watershed processes and management activities on erosion.

During the past decades, many models have been proposed for soil erosion prediction [8], [16]-[20]. A number of models and approaches such as Coordination of Information on the Environment (CORINE), Universal Soil Loss Equation (USLE), Erosion Kinematic Wave Models, and Discrete Dynamic Models (DDM) have been developed to assess or predict soil erosion hazards [16], [18]. These empirical models and other semi-quantitative approaches play an important role in environmental risk assessment across the globe because of their simple structure and ease of application [21].

To determine the erosion risks and quality of lands in the countries of the European Union (EU), the CORINE model was developed from the Universal Soil Loss Equation (USLE), which is a well-known methodology in soil erosion prediction [21]-[27]. It is an empirical model which can predict soil erosion in a spatially explicit manner. CORINE involves designing and overlaying several layers of thematic maps, and it can present the spatial heterogeneity of soil erosion risk within a GIS environment [28], [29]. It also has the advantage of having a simple structure and is easy to apply with GIS. CORINE is being widely applied by European and Mediterranean countries for soil erosion risk assessment, and has correctly identified areas which have the highest susceptibility to erosion [21], [26]-[28], [30]-[32]. To estimate actual erosion risk in the CORINE model, the required input databases are soil erodibility, rainfall erosivity, topography (slope), and land use/cover (vegetation cover). The objective of the present research is to assess the spatial heterogeneity of soil erosion risk and identify erosion hotspot areas, aiming to counteract ongoing land degradation using experimentally proven Soil and Water Conservation (SWC) interventions.

\section{Materials and Methods}

\subsection{Description of the Study Watershed}

The study area is the Gumara-Maksegnit watershed which is located in the southern part of the Amhara Region, Ethiopia. The watershed is in the north of the Gondar province and is located about $45 \mathrm{~km}$ southwest of Gondar town. The geographical location is between $12^{\circ} 23^{\prime} 53^{\prime \prime}$ to $12^{\circ} 30^{\prime} 49^{\prime \prime}$ latitude and $37^{\circ} 33^{\prime} 39^{\prime \prime}$ to $37^{\circ} 37^{\prime} 14^{\prime \prime}$ longitude (Figure 1).

This mountainous agricultural watershed, which covers an area of $53.7 \mathrm{~km}^{2}$, is one of the most severely eroded parts of the Ethiopian highlands [33]. The study watershed has a very rugged mountainous topography, with an average slope of $22.1 \%$ and most the study watershed (more than $90 \%$ of the area) is composed of gullies and ridges. The elevations of the watershed range from $1920 \mathrm{~m}$ to $2850 \mathrm{~m}$ above sea level [33]. The area's geology is dominated by Trapp series of Tertiary volcanic eruptions [33]. The soil types of the watershed are classified as Cambisols and Leptosols, which cover the upper and central parts of the area, and as Vertisols in the lower parts of the watershed near the outlet. There are five different soil textural classes within the Gumara-Maksegnit watershed, namely: sandy clay loam, sandy loam, clay loam, loam, and clay [33]. The land use types of the watershed are mainly agricultural land (63.5\%) followed by mixed forest (24.3\%) and grazing land (12.2\%) [34]. The study area is characterized by a bi-modal rainfall distribution with an annual mean value of $1170 \mathrm{~mm}$. The mean minimum and maximum temperatures are 13.3 and $28.5^{\circ} \mathrm{C}$, respectively.

\subsection{Methodology}

The total area of the Gumara-Maksegnit watershed was divided into a $500 \mathrm{~m}$ by $500 \mathrm{~m}$ square grid and approximately at the center of each grid soil samples were collected at 234 locations over the entire territory of the watershed using auger and core cylinder equipment. Soil sampling points were located by using hand held Garmin explorer GPS. Each soil sample was taken from approximately the center of grid; however, some sampling points were shifted from the center of the grid due to difficult topographic conditions. Soil samples of about $2 \mathrm{~kg}$ were taken from the surface soil horizon, which ranged from 0 to $25 \mathrm{~cm}$ based on the topsoil depth, with the best available tool (bucket auger) for soil physical property analysis. Soil particle size distribution was determined by the Bouyoucos hydrometric method after destroying organic matter $(\mathrm{OM})$ using hydrogen peroxide $\left(\mathrm{H}_{2} \mathrm{O}_{2}\right)$ and dispersing the soils with sodium hexametaphosphate $\left(\mathrm{NaPO}_{3}\right)$. Soil depth was determined through excavation of soil mass until the bedrock was encountered. 


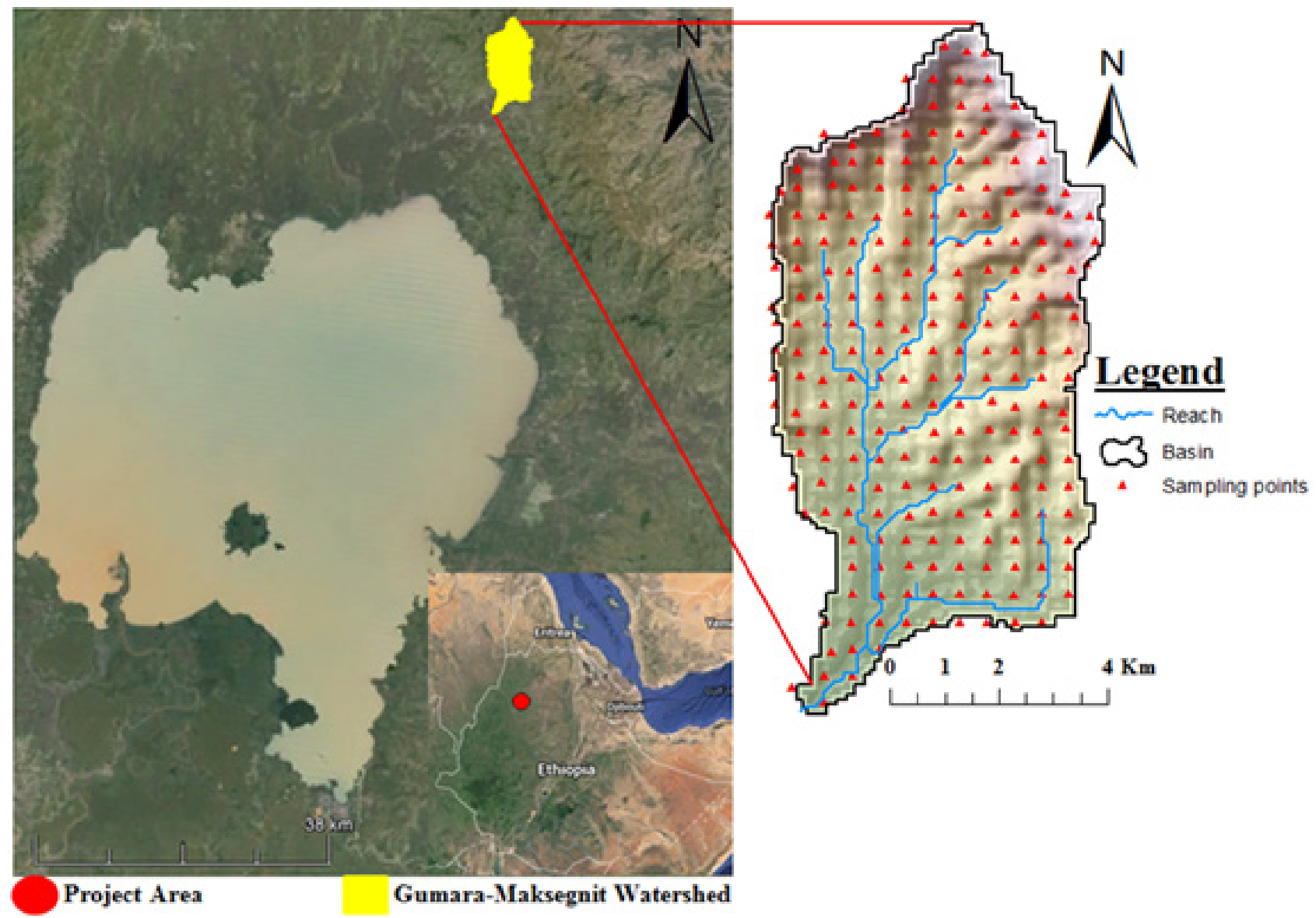

Figure 1: Overview of the project watershed area and the 234 soil sampling sites.

To predict actual and/or potential erosion risk using the CORINE model, the required input data are erodibility, rainfall erosivity, topography and land use. The parameters are represented as four separate indices, which are then combined to evaluate erosion risk of the study watershed (Figure 2). The model consists of six steps, each of which uses different overlaying combinations of soil texture, depth, stoniness, climatic data, land use and land cover information. Initially, soil texture, soil depth, and surface stoniness maps were created and intersected in an ArcGIS environment to generate an erodibility map. The prepared vector soil analysis data was previously re-organized and reclassified based the CORINE methodology. For computing rainfall erosivity, Fournier precipitation (FI) and BagnoulsGaussen aridity indices (BGl) were determined based on seventeen years of meteorological data, as follows:

$F I=\sum_{i=1}^{12} \frac{p i^{2}}{p}$ and $B G I=\sum_{i=1}^{12}(2 t i-p i) * K i$

Where, $(P i)$ is total precipitation in a month, $(P)$ total mean annual precipitation, $(t i)$ mean temperature for the month, and $(K i)$ the proportion of the month during which $2 t i-P i>0$.

The soil erodibility map was then co-evaluated with rainfall erosivity values and a slope map of the site to compose the potential erosion risk map. Finally, the land cover and potential soil erosion risk layers were combined to form the actual soil erosion risk map. In this study, Digital Elevation Model (DEM) data was collected from the Shuttle Radar Topography Mission (SRTM), while the ArcGIS program and its extensions (3D Analyst and Spatial Analyst tool) were used to perform the required analyses.

\section{Results and Discussion}

\subsection{Soil Erodibility}

The results of the soil lab analysis in Table 1 showed that the soil texture classes in the study watershed are sandy loam and loam (73 $\%)$, clay loam (21.6\%), and clay (5.4\%). Therefore, the soils of the study area have low ability to resist soil erosion since sandy loam and loam textural classes are highly susceptible to erosion based on the CORINE model.

In terms of depth, the soil is categorized as very shallow (62.01\%), shallow (30.17\%), and moderately deep (7.82 \%), which results in high erosion rates due to their lower water holding capacity and higher overland flow. The results also indicate that $63.31 \%$ of the study area has less than $10 \%$ stoniness, while the rest of the watershed has 


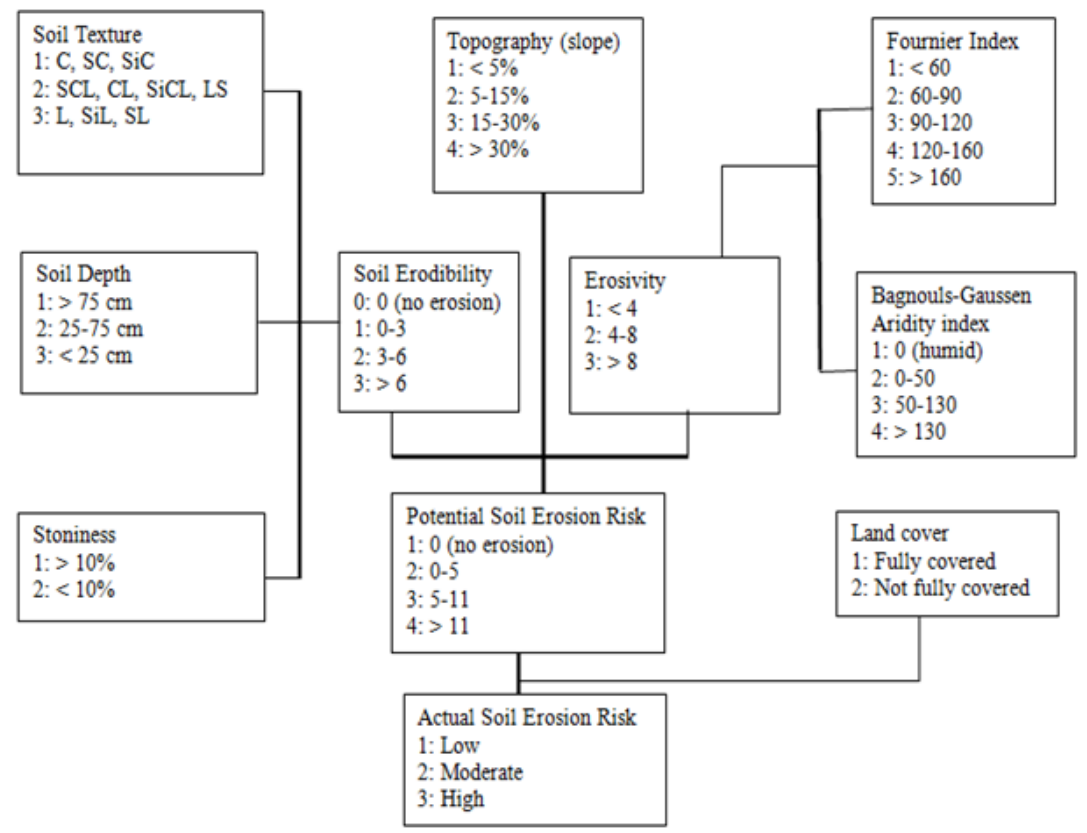

Figure 2: Flow diagram of CORINE soil erosion assessment model.

Table 1: Summary of selected soil lab analyses of texture, depth, stoniness and soil erodibility.

\begin{tabular}{|c|c|c|c|c|c|c|c|c|c|c|c|c|c|c|}
\hline \multicolumn{4}{|c|}{ Soil Texture } & \multicolumn{4}{|c|}{ Depth $(\mathrm{cm})$} & \multicolumn{4}{|c|}{ Stoniness (\%) } & \multicolumn{3}{|c|}{ Soil Erodibility } \\
\hline $\begin{array}{c}\text { CORINE } \\
\text { Code }\end{array}$ & $\begin{array}{c}\text { CORINE } \\
\text { Class }\end{array}$ & Area $\left(\mathrm{km}^{2}\right)$ & Area (\%) & Code & Class & Area $\left(\mathrm{km}^{2}\right)$ & Area (\%) & Code & Class & Area $\left(\mathrm{km}^{2}\right)$ & $\begin{array}{c}\text { Area } \\
(\%)\end{array}$ & Code & Area $\left(\mathrm{km}^{2}\right)$ & Area (\%) \\
\hline 1 & C & 2.9 & 5.40 & 1 & $>75$ & 4.2 & 7.82 & 1 & $>10$ & 19.7 & 36.69 & 1 & 2.1 & 3.91 \\
\hline 2 & $\mathrm{CL}$ & 11.6 & 21.60 & 2 & $25-75$ & 16.2 & 30.17 & 2 & $<10$ & 34 & 63.31 & 2 & 11.5 & 21.42 \\
\hline 3 & SL and $L$ & 39.2 & 73.00 & 3 & $<25$ & 33.3 & 62.01 & & & & & 3 & 40.1 & 74.67 \\
\hline Total & & 53.7 & 100 & & & 53.7 & 100 & & & 53.7 & 100 & & 53.7 & \\
\hline
\end{tabular}

more than $10 \%$ stoniness. The soil erodibility map of the study watershed (Figure 3A) was generated by overlapping the physical properties of the soil such as texture, depth, and stoniness using the ArcGIS environment. The resulting erodibility map indicates that $21.42 \%$ of the study watershed is covered by moderately erodible soil, while $3.91 \%$ and $74.67 \%$ is covered by low and highly erodible soil, respectively.

As presented in Figure 3A in the map of the spatial distribution of soil erodibility, the southern part and northern edge of the watershed are moderately erodible and slightly erodible since the area is highly dominated by clay soil particles and gentle to flat slope. While the northern, western, and eastern parts of the watershed are highly erodible because of their sandy dominated texture and steep slope.

Soil erodibility depends primarily on the structural stability of the soil (and hence its resistance to particle detachment by rainfall splash or runoff) and on its ability to absorb rainfall. However, this watershed is unable to resist detachment due to the poor quality of the soil's physical properties, such as texture and depth.

\subsection{Topography}

The slope data layer was derived from a Digital Elevation Model (DEM) of the study area and classified based on the CORINE model (Figure 3B). The results showed that about $56.2 \%$ of the study area has more than $15 \%$ slope, ranging from steep to very steep terrain, which may significantly increase soil erosion due to runoff. The rest of the study area lies on terrain with less than $15 \%$ slope, ranging from very gentle to gentle. The spatial results in Figure 3B show that the northern, eastern and western edges of the watershed are dominated by very steep slopes, while the southern part is characterized by flat and gentle slopes. However, the central and eastern part is characterized by gentle to steep slope classes.

\subsection{Vegetation Cover}

The land cover map of the study watershed was produced on the pixelbased supervised classification of a $10 \mathrm{~m}$ spot satellite image and this land use map was used for this research. The largest area (63.5\%) of the watershed was found to be crop land, $24.3 \%$ is forest, and $12.2 \%$ pasture. The vegetation cover layer is reclassified into two vegetation indices including fully protected and not fully protected, based on the CORINE method. Thus, in the study watershed, forest and shrubs are classified as fully protected (24.3\%), while cultivated land, bare land, and pasture/rangeland are classified as not fully protected (75.7 $\%$ ). In terms of the spatial distributions of the vegetation map (Figure $3 C)$, the southern, northern and southwestern edges, and some parts 

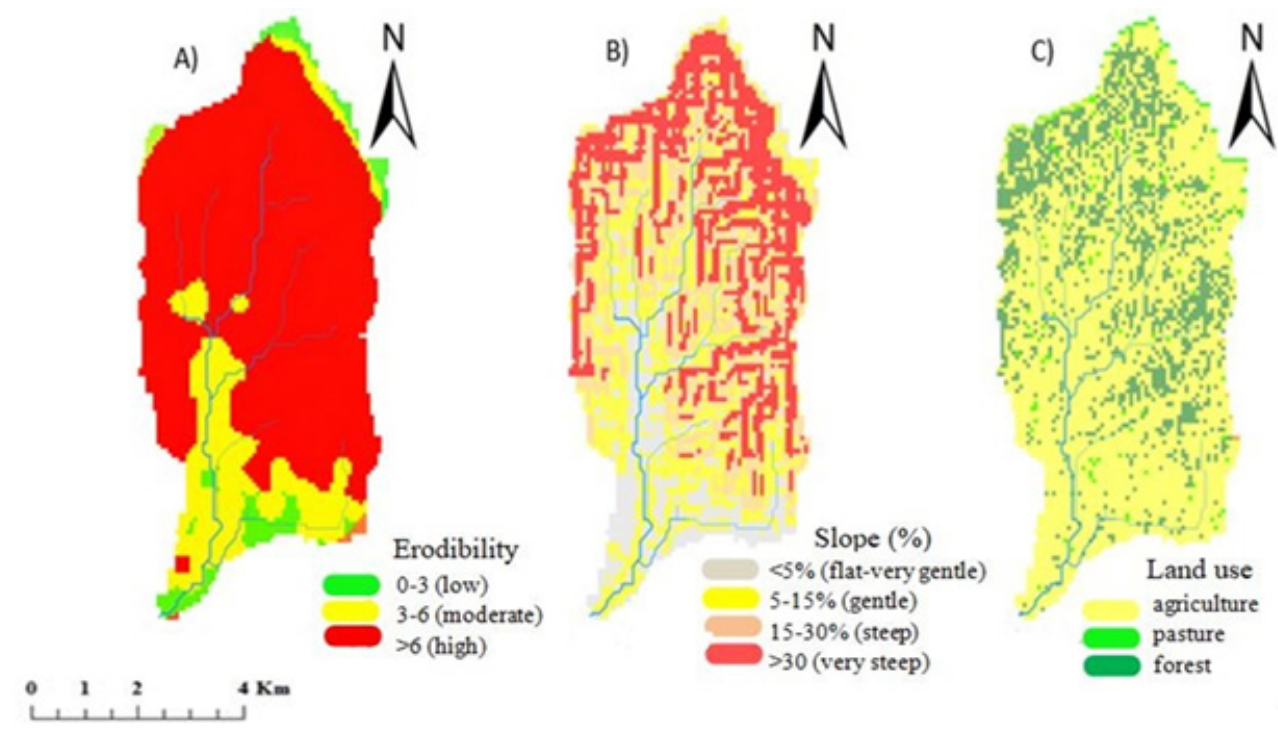

Figure 3: Gumara-Maksegnit watershed maps showing (A) erodibility, (B) slope classes and (C) land use types.

of the central watershed are not fully protected and are specifically dominated by cultivated and rangeland land use types, while the eastern and northwestern parts are fully protected areas.

\subsection{Erosivity}

In terms of climatic factors, both precipitation and temperature play an important role in the soil's physical and chemical properties. In the CORINE methodology, the Fournier Index (FI) as precipitation index and Bagnouls-Gaussen index $(\mathrm{BGI})$ as temperature index were calculated based on seventeen years of metrological data at four stations located in the watershed. The Fl of the study area was calculated as 236.74 for metrological station one, which was classified as very high, 235.61 for the second station (very high), 236.25 for the third station (very high), and 234.21 for fourth station (very high). Thus, the aggregate $\mathrm{FI}$ index was also classified as very high. The BGI was found to be 107.41 for the first station, which is classified as dry, 92.59 for the second station (dry), 110.69 for the third station (dry) and 110.7136 for the fourth station (dry). As with the Fl, the aggregate BGI was classified as dry. The FI and the BGI indices were then combined to generate the erosivity layer. The results indicate that the erosivity index is high for the study area and falls under CORINE class three, while it was also found that erosivity is similar throughout the whole watershed.

As experienced in northern Ethiopia as a whole and in the study area particularly, rain tends to fall as heavy downpours. The extent of erosion caused by rainfall (erosivity) depends on the size and velocity of raindrops and the amount of precipitation. As the FI result indicates, the rain is highly erosive due to its intensity and amount. High-intensity storms produce larger drops that fall faster than those of low-intensity storms and therefore have greater potential to destroy aggregates and dislodge particles from the soil matrix. A short, high-intensity rainfall event causes much more erosion than a long, low-intensity event and in this case the watershed experiences short-term erosive rainfall in three consecutive moths (June, July and August).

The CORINE model also considered temperature as a climatic factor of soil erosion, because temperature has an indirect effect on the nature and rate of soil erosion. The BGI index is under class five of the CORINE model, which is dry. Alternate wet and dry conditions result in hydration and dehydration of the thin veneer of soil. This leads to expansion of soil particles resulting in cracks which, if filled with water during the rains, cause the removal of soil. However, frozen soils are more resistant to erosion as soil particles stick together. Moreover, when the temperature is either cold or warm it is coupled with wind. This wind is one of the eroding agents of soil erosion if it continues in the dry season. Wind which blows during rainfall events, however, can deflect raindrops and minimize their kinetic energy. Consequently, the potential of the rain to detach soil particles reduced.

\subsection{Potential Soil Erosion Risk}

After calculation of the above input parameters of the CORINE model, the potential soil erosion risk map was generated by overlapping the soil erodibility, erosivity and slope layers (Figure 4A). The resulting potential soil erosion risk map showed that only $6.63 \%$ of the study area was classified as low potential erosion risk, while a large part of the area (75.45 \%) is under high potential erosion risk. The rest of the area $(17.92 \%)$ is under moderate potential soil erosion risk.

The results also indicate that the areas with high erosion risk are in the northwestern and northeastern parts of the study watershed, while the areas with low erosion risk are located in the southern edge and the central part of the watershed, representing a very small area relative to the total watershed. Meanwhile, moderately erodible areas are found in the southern area, northwestern edge and randomly distributed in the central part of the watershed. 

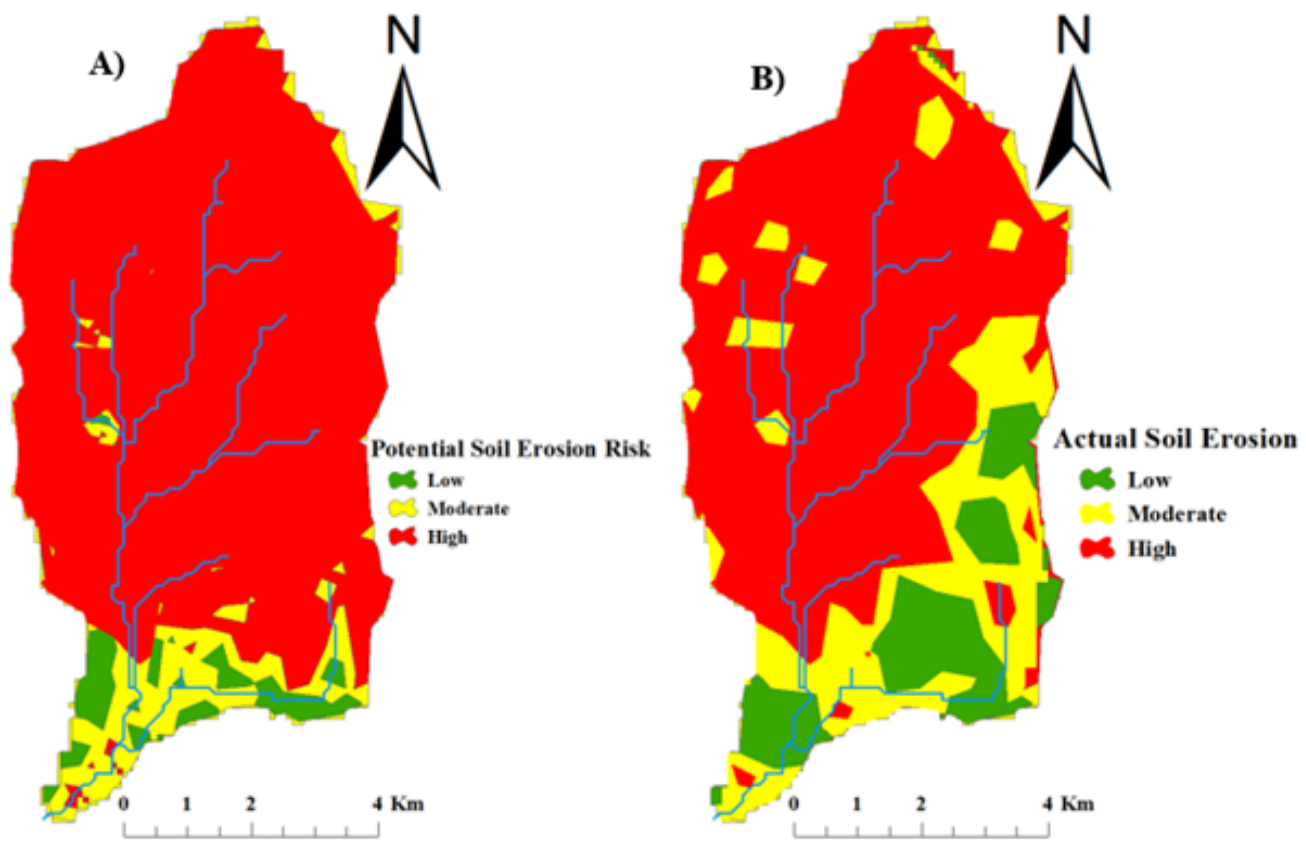

Figure 4: Gumara-Maksegnit watershed maps showing (A) potential soil erosion risk and (B) actual soil erosion risk.

\subsection{Actual Soil Erosion Risk}

In the final step, the CORINE actual soil erosion risk map was generated by overlapping the land cover map and the potential soil erosion risk map. The actual soil erosion risk map result shows that the study watershed has $11.92 \%$ low, $20.85 \%$ moderate, and 67.23 $\%$ high erosion risk levels. From the results, it can be observed that the difference between the areas of potential and actual erosion risk reflects the protective influence provided by the present land cover. In particular, $75.45 \%$ of the area classified as having high erosion risk in the potential soil erosion risk map decreased to $67.23 \%$ in the actual soil erosion risk map. In addition to this, while about $6.63 \%$ was classified as having low erosion risk in the potential soil erosion risk map, after overlapping the vegetation layer, low erosion risk areas increased to about $11.29 \%$.

The actual soil erosion risk map (Figure 4B) shows that the northern, eastern and northwestern parts of the watershed are under high erosion risk, while the southern area is under less erosion risk, and the moderately risky areas are randomly distributed in the northern and central part of the watershed.

The actual soil erosion risk map leads to the conclusion that almost all parts of the watershed in the northern, eastern and western areas are dominated by high soil erosion risk and require emergency intervention. Only the southern part of the watershed and some portions on the northern edge as well as very small portions of the central area are at less soil erosion risk, and these may not need immediate attention for soil conservation measures. On the other hand, moderately erodible lands are distributed randomly in the northern and central parts of the watershed. Overall, management measures can be designed based on the map and priority should be given for high erosion risk parts of the watershed (Figure 5).

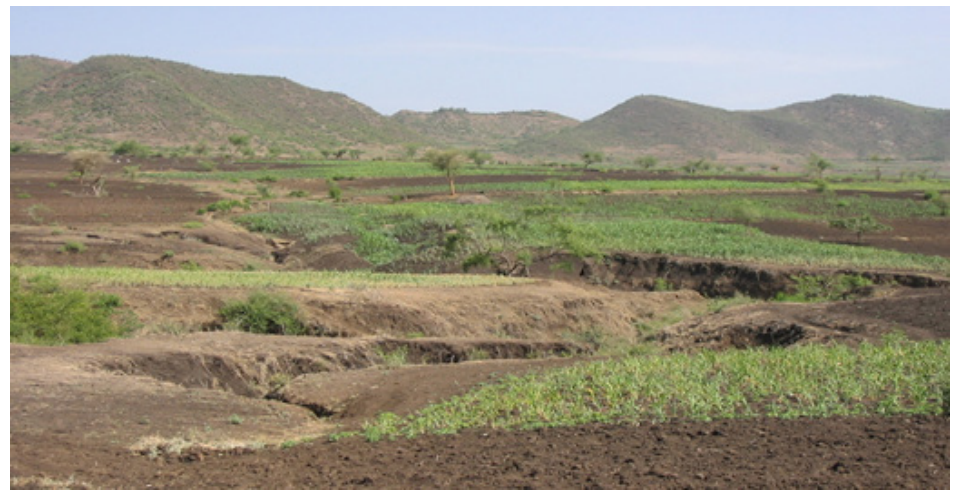

Figure 5: Active gully in the Gumara-maksegnit watershed.

\section{Conclusions}

Rainfall driven soil erosion is a frequent problem in the Ethiopian highlands, thus the modeling and quantitative estimation of erosion processes along with impact assessment are required. The Coordination of Information on the Environment (CORINE) soil erosion assessment method was used here in conjunction with ArcGIS to assess the spatial heterogeneity of soil erosion risk in the GumaraMaksegnit watershed, in the northwest Amhara region of Ethiopia.

The resulting potential soil erosion risk map showed that small parts of the watershed (6.63\%) had low risk, $17.92 \%$ of the area had moderate risk and a large part of the study area (75.45 \%) had high potential soil erosion risk. 
On the other hand, the actual soil erosion risk map showed that a small part of the watershed area (11.92 \%) had low risk, $20.85 \%$ of the area had moderate risk and a large part of the study area $(67.23 \%)$ had high actual soil erosion risk. The low soil erosion risk areas are located in the southern part of the watershed. High erosion risk areas are found in the northwestern and eastern part of the watershed, whereas moderately risky areas are randomly distributed in the watershed. The southern parts of the study area have gentle slopes or have flat topography; thus, this area has low and moderate erosion risk. The vegetation cover data is a very important parameter in erosion models since the intensity of vegetation cover significantly affects erosion rates. The difference between potential soil erosion and actual soil erosion is due to vegetation cover.

The study demonstrates that the CORINE model together with ArcGIS is a useful tool to locate the most endangered areas due to erosion and facilitates sustainable land management through conservation planning. The method can thus be applied in other parts of Ethiopia for assessment and prioritization of areas for soil conservation. The CORINE method is an efficient use of limited resources and does not account for the socio-economic parameters or the chemical properties of the soil in the erosion assessment; therefore, its application is appropriate in situations of limited resources. Nevertheless, future soil erosion studies that consider physical, chemical and biological soil properties, in addition to socio-economic parameters could be vital.

\section{References}

[1] D. Pimentel and M. Burgess, "Soil erosion threatens food production," Agriculture, vol. 3, no. 3, pp. 443-463, Aug. 2013. Doi: https://doi.org/10.3390/ agriculture 3030443

[2] A. D. Zegeye, "Assessment of upland erosion processes and farmer's perception of land conservation in Debre-Mewi watershed, near Lake Tana, Ethiopia," M.S. thesis, Faculty of Graduate School, Cornell University, 2009.

[3] K. Esser and M. Haile, "Soil conservation in Tigray," Noragric, Centre for Int.Environ. and Development Studies, Agric. Univ. of Norway, Rep. 5, 2002.

[4] A. Mushir and S. Kedru, "Soil and water conservation management through indeigenous and traditional practices in Ethiopa: a case study," Ethiopian Journal of Environmental Studies and Management, vol. 5, no. 4, pp. 343-355, Aug. 2012. Doi: https://doi.org/10.4314/ejesm.v5i4.3

[5] S. Thiemann, "Assessment of erosion and soil erosion processes - a case study from the Northern Ethiopian Highland," Topics of Integrated Watershed Management Proc., vol. 3, 2005, pp. 173-185.

[6] K. K. Beyene, "Soil erosion, deforestation and rural livelihoods in the Central Rift Valley area of Ethiopia: a case study in the Denku micro- watershed Oromia region," M.S. thesis, Dept. of Agriculture, Animal Health and Human Ecology, University of South Africa, Pretoria, 2011.

[7] W. Z. Zhao, H. L. Xiao, Z. M. Liu and J. Li, "Soil degradation and restoration as affected by land use change in the semiarid Bashang area, northern China," Catena, vol. 59, no. 2, pp. 173-186, 2005. Doi: https://doi.org/10.1016/j.catena.2004.06.004

[8] J. De Vente, J. Poesen and G. Verstraeten, "The application of semi-quantitative methods and reservoir sedimentation rates for the prediction of basin sediment yield in Spain," Journal of Hydrology, vol. 305, no. 1-4, pp. 63-86, 2005. Doi: https:// doi.org/10.1016/j.jhydrol.2004.08.030
[9] A. Inman, "Soil erosion in England and Wales: causes, consequences and policy options for dealing with the problem," Discussion Paper prepared for WWF, Godalming, Surrey, Feb. 2006.

[10] Ontario Ministry of Agriculture - Food and Rural Affairs, "Soil erosion causes and effects: Introduction Erosion by Water," Ontario Institute of Pedology [Online]. Available: http://www.envirothon.org/files/curriculum/soil/soil erosion.pdf

[11] S. K. Jain, S. Kumar and J. Varghese, "Estimation of soil erosion for a Himalayan watershed using GIS technique," Water Resour. Manag., vol. 15, no. 1, pp. 41-54, 2001. Doi: https://doi.org/10.1023/a:1012246029263

[12] M. Koulouri and Chr. Giourga, "Land abandonment and slope gradient as key factors of soil erosion in Mediterranean terraced lands," Catena, vol. 69, pp. 274281, 2007. Doi: https://doi.org/10.1016/j.catena.2006.07.001

[13] Y. Le Bissonnais, C. Montier, M. Jamagne, J. Daroussin and D. King, "Mapping erosion risk for cultivated soil in France," Catena, vol. 46, no. 2-3, pp. 207-220, 2002. Doi: https://doi.org/10.1016/s0341-8162(01)00167-9

[14] N. Haregeweyn, "Assessing the performance of a spatially distributed soil erosion and sediment delivery model (watem/sedem) in Northern Ethiopia," Land Degrad. Dev., vol. 24, no. 2, pp. 188-204, May 2011. Doi: https://doi.org/10.1002/ldr.1121

[15] D. Tibebe and W. Bewket, "Surface runoff and soil erosion estimation using the SWAT model in the Keleta Watershed, Ethiopia," Land Degrad. Dev., vol. 22, no. 6, pp. 551-564, Aug. 2010. Doi: https://doi.org/10.1002/ldr.1034

[16] A. Cilek, S. Berberoglu, M. Kirkby, B. Irvine, C. Donmez and M. A. Erdogan, "Erosion modelling in a mediterranean subcatchment under climate change scenarios using Pan-European Soil Erosion Risk Assessment (PESERA)," ISPRS - Int. Archives of the Photogrammetry, Remote Sensing and Spatial Information Sciences, vol. XL-7/W3, pp. 359-365, Apr. 2015. Doi: https://doi.org/10.5194/isprsarchives-xl7-w3-359-2015

[17] R. Hessel, J. Daroussin, S. Verzandvoort and D. Walvoort, "Evaluation of two different soil databases to assess soil erosion sensitivity with MESALES for three areas in Europe and Morocco," Catena, vol. 118, pp. 234-247, Jul. 2014. Doi: https://doi.org/10.1016/j.catena.2014.01.012

[18] A. J. Parsons, J. Wainwright, D. M. Powell, J. Kaduk and R. E. Brazier, "A conceptual model for determining soil erosion by water," Earth Surf. Proc. Land., vol. 29, no. 10, pp. 1293-1302, Sep. 2004. Doi: https://doi.org/10.1002/esp.1096

[19] J. de Vente and J. Poesen, "Predicting soil erosion and sediment yield at the basin scale : Scale issues and semi-quantitative models," Earth-Sci. Reviews vol. 71, no. 1-2, pp. 95-125, Jun. 2005. Doi: https://doi.org/10.1016/j.earscirev.2005.02.002

[20] H. Aksoy and M. L. Kavvas, "A review of hillslope and watershed scale erosion and sediment transport models," Catena, vol. 64, no. 2-3, pp. 247-271, Dec. 2005. Doi: https://doi.org/10.1016/j.catena.2005.08.008

[21] A. İmamoglu, I. D. Turan, O. Dengiz and F. Saygin, "Soil erosion risk evaluation : Application of Corine Methodology at Engiz Watershed, Samsun," Current Advances in Environmental Science, vol. 2, no. 1, pp. 15-21, 2014.

[22] N. Bayramin, G. Erpul and H. E. Erdogan, "Use of CORINE Methodology to assess soil erosion risk in the semi-arid area of Beypazar, Ankara," Turk. J. Agric. For., vol. 30, pp. 81-100, 2006.

[23] A. Aydin and H. B. Tecimen, "Temporal soil erosion risk evaluation: A CORINE methodology application at Elmah dam watershed, Istanbul," Environ. Earth Sci., vol. 61, no. 7, pp. 1457-1465, 2010. Doi: https://doi.org/10.1007/s12665-010$\underline{0461-2}$

[24] W. Sun, Q. Shao, J. Liu and J. Zhai, "Assessing the effects of land use and topography on soil erosion on the Loess Plateau in China," Catena, vol. 121, pp. 151-163, Oct. 2014. Doi: https://doi.org/10.1016/j.catena.2014.05.009

[25] A. Yuksel, R. Gundogan and A.E. Akay, "Using the remote sensing and GIS technology for erosion risk mapping of Kartalkaya dam Watershed in Kahramanmaras, Turkey," Sensors, Vol. 8, no. 8, pp. 4851-4865, 2008. Doi: https://doi.org/10.3390/s8084851 
[26] O. D. Z, "Soil erosion risk assessment of the Gölbaşl environmental protection area and its vicinity using the CORINE Model," Turk. J. Agric. For., vol. 29, pp. 439-448, 2005 .

[27] M. Zhu, "Soil erosion assessment using USLE in the GIS environment: a case study in the Danjiangkou reservoir region, China," Environ. Earth Sci., vol. 73, no. 12, pp. 7899-7908, Dec. 2014. Doi: https://doi.org/10.1007/s12665-014-3947-5

[28] M. B. Vega, J. M. Febles, A. Tolón, and X. Lastra, "Potential soil erosion assessment through the CORINE methodology in cattle districts of the Mayabeque province, Cuba," Cuban J. Agr. Sci., vol. 45, no. 4, pp. 423-428, 2011.

[29] R. E. Ekpenyong "An assessment of land cover change and erosion risk in Akwa Ibom State of Nigeria using the Co-ordination of Information on the Environment (CORINE) methodology," Greener Journal of Physical Sciences, vol. 3, no. 3, pp. 076-089, 2013.

[30] M. Erhard, H. Böken, and F. Glante, "The assessment of the actual soil erosion risk in Germany, based on CORINE land-cover and statistical data from the main representative survey of land use," pp. 1-12. 2011.

[31] S. Bashir, M. A. Baig, M. Ashraf, M. M. Anwar, M. N. Bhalli and S. Munawar, "Risk assessment of soil erosion in Rawal watershed using geoinformatics techniques," Science International, vol. 25, no. 3, pp. 583-588, 2013.

[32] M. Zhu, "Soil erosion risk assessment with CORINE model: Case study in the Danjiangkou Reservoir region, China," Stoch. Env. Res. Risk A., vol. 26, no. 6, pp. 813-822, 2012. Doi: https://doi.org/10.1007/s00477-011-0511-7

[33] H. K. Addis, A. Klik, and S. Strohmeier, "Spatial variability of selected soil attributes under agricultural land use system in a mountainous watershed, Ethiopia," Int. J. of Geosciences, vol. 6, no. 6, pp. 605-613, Jun. 2015. Doi: https://doi.org/10.4236/ ijg.2015.66047

[34] H. Kendie and A. Klik, "Predicting the spatial distribution of soil erodibility factor using USLE nomograph in an agricultural watershed, Ethiopia," Int. Soil Water Conserv. Res., vol. 3, no. 4, pp. 282-290, Dec. 2015. Doi: https://doi.org/10.1016/j. iswcr.2015.11.002 